\title{
Application and Practice of Experiential English Teaching in Higher Vocational Colleges
}

\author{
Liu Hongwei, Wang Hui, Zhang Xin \\ Weifang Vocational College, Weifang 261041, Shandong, China
}

\begin{abstract}
Experiential teaching model, which is widely used in English teaching of higher vocational colleges, conforms to the cognitive rules of students and fully reflects the student-oriented and teacher-guided teaching concept. By analyzing the application and practice of this teaching method in higher vocational English teaching, the paper summarizes the advantages of the method, such as cultivating students' learning interest, conforming to the learning characteristics of higher vocational students, enhancing students' logical thinking and language expression ability. But this teaching method also has some limitations, including difficulty in practice, time consuming, poor universality and less emphasis on reading. This paper puts forward some teaching suggestions, such as collaborative lessonplanning.
\end{abstract}

Keywords-Higher vocational English teaching; Experiential teaching method; Application and practice

\section{INTRODUCTION}

With the ongoing reform in education, China has continuously approved various supporting policies for developing higher vocational education in recent years, thus training high-quality applied talents to meet the increasingly diverse and differential social demand for talents and boost the local economy. Especially after the 13th Five-Year Plan and the Belt and Road Initiative being put forward, English has gone deep into all aspects of the economic and social life as the most widely used languages in the world. Therefore, English is becoming more and more important in the curriculum construction of higher vocational colleges. As a public basic course, its teaching objective is to develop the application ability of students. Under the policy of practical and sufficient education, higher vocational English should teach students the basic linguistic knowledge and the practical ability to use English. Nowadays, higher vocational colleges have made great improvement both in the hardware and software construction, and their teachers also keep growing stronger. All these facts provide the implementing condition for experiential English teaching in higher vocational colleges.

\section{CONCEPT AND BASIS OF EXPERIENTIAL ENGLISH TEACHING}

The concept of experiential education was put forward by John Dewey (1859-1952, American educationist, psychologist, and philosopher), representative of pragmatic education, at the beginning of the 20th century. American social psychologist David Kolb put forward the experiential learning theory systematically in 1984 and explained it in a theoretical level. Experiential teaching is from experience, whose subject is student. It is student-centered, activity-centered and experience-centered, containing 4 stages: concrete experience, reflective observation, abstract conceptualization and active experimentation [1]. In the process of experiential teaching, teacher is a co-worker or mentor, who creates a situation or simulates a reality and guide students to complete these 4 stages. Therefore, students can better apply what they learned, give a timely response to the problems encountered during learning and generate a process summary of learning, which increases students' self-confidence and learning effect.

Experiential English teaching model goes with the current English teaching reform and focuses on the training of practical and vocational abilities and autonomous learning of students. Teachers concern the professional characteristics of different majors and the future career situation during teaching, and ask students to play certain roles or accomplish tasks by using English knowledge. The 4 stages of experiential learning are "circulating, spiraling and deepening", which help students gradually digest the knowledge in the learning process, then master and apply it as their own knowledge. [2] At the same time, Experiential English teaching pays attention to each student's emotion, stimulates students' interest in learning English, helps them build self-confidence, improves their humanistic quality and practical ability, and generates creative spirit. Therefore, experiential English teaching is a model of "student-centered, project-based and task-driven", enabling students to discover the rules of using English through "simulated situation experience" and apply the linguistic and grammatical knowledge in actual communication [3]. 


\section{The fundamental change of teacher's roles in classroom}

The experiential English teaching model changes the traditional teaching model-teacher-centered and delivered by lecturing. Fundamental changes have taken place in the roles of teachers in classroom: from leader to situation designer, activity guide and facilitator.[5] Before class, teachers firstly need to deeply analyze the learning conditions of students, then go into deep study of teaching content and key points and difficult points of knowledge based on teaching goals, and design a learning situation according to the results of the analysis, and make preparation for the simulated situation (pictures, audio and video teaching materials, props, etc.) In teaching process, teacher plays the roles of activity guide and facilitator, and observes actively and mobilizes students' emotion in order to lead students to experience and practice. After the experiential activity, teachers should summarize and assess students' cognition formed in the process of experiencing, and get ready for entering a new experience.

\section{Diverse and all-around evaluation methods}

Dr. Dai Jiagan (2008:1) once said that "the focus of improving education quality and examination reform is to build a scientific exam and evaluation system compared to traditional exams, and update examination into multivariate evaluation. That is the core issue of examination reform, and also the key to education reform." [6]The traditional evaluation method is mostly written examination, that means test score is the only evaluation standard to students. It ignores the training of linguistic competence and study process, uses only a single evaluation index, which harms students' dominant role and creativity generation. Experiential English teaching uses multiple evaluation methods, which root in formative assessment and diagnostic evaluation. It not only evaluates the accuracy, fluency, and appropriateness of students' learning and application of language knowledge but also assess the students' participation and cooperation ability. The subjects of evaluation is not only teacher compared with the traditional way. There are teacher-evaluation, student-evaluation, groupevaluation, etc. The diversified teaching resources and more scientific evaluation system greatly improved student's initiative and efficiency of learning.

\section{APPLICATION AND PRACTICE OF EXPERIENTIAL ENGLISH TEACHING IN HIGHER VOCATIONAL COLLEGES}

Experiential English teaching emphasizes students' initiative and its teaching design should conform to the theory of circulation and the growth of students' learning. Through the classroom practice, experiential English teaching can be divided into 4 stages: preparation before class, in-class experiencing and feeling, in-class knowledge summary and evaluation, and language application after class. These 4 stages interact with and include each other. 


\section{A. Pre-class preparation}

This stage is about teachers' teaching preparation. First, teachers should analyze the learning situation, study the teaching content according to the students' English level, then determine the specific objectives of knowledge, capabilities, and quality. Then teachers could creatively design a teaching situation and different language situations in workplaces. In this process, teachers need to collect a lot of materials, such as language material (vocabulary, reading material), situation material (pictures, props, decoration), audio and visual material (speech, record, original English movies, audio and video clips, etc.) and the tasks students need to finish. All kinds of materials should be well-prepared and made into a multimedia courseware, so as to create a real language environment and let students fit in the situation. At the same time, ask students to finish some self-study tasks with the teaching materials, network or mobile platforms before class to make sure they would actively preview some related language materials.

\section{B. classtime experience and feelings}

The experience of simulated situation is the key part in experiential English teaching. On the one hand teachers should explain the objectives, tasks and rules of the experiential activity, on the other hand teachers need to design a project and blend occupational activities in class according to the students' knowledge levels, majors and personalities, fully use the materials prepared before class and lead students to participate into activities in order to promote their experience and feeling. While guiding students to experience the situation, teachers should observe students, grasp the speed of class teaching, motivate students' emotion, create a relaxed and harmonious class atmosphere, encourage and help students to actively participate and experience the English application in a real communication situation, and produce their own feelings and awareness.

\section{The summary of class knowledge}

Through class experience, students have already acquired some language knowledge. Combined with the knowledge studied before class, they can discuss, exchange and share in groups to sum up the application and communicative rules of the language; on the basis of students' summary, teachers could summarize again and make comments, also teach more about the usage of language points in different contexts and their variation, so as to reach teaching requirements.

\section{After-class language application}

After class, with the questions given by teachers, students should use, experience and summarize the language points through teaching materials, network and multimedia courseware. Then, under the guidance of teachers, students need to integrate the language points summarized by themselves and apply them in a new context, obtain new experience and get ready for the next experience.

\section{ADVANTAGES AND LIMITATIONS OF EXPERIENTIAL}

\section{ENGLISH TEACHING IN HIGHER VOCATIONAL COLLEGES}

Through the application and practice mentioned above, experiential English teaching show the advantages as follows:

(1)Raising students' learning interest and enthusiasm. Through creating situations, experiential teaching strengthens students' practical application of language, rather than teaching language knowledge only.

(2)According to the learning characteristics of higher vocational students, experiential English teaching realizes the share of study materials and interactive learning on platforms through network, multimedia techniques and mobile phones, thus the students' ability to listen, speaking, reading and writing can be improved.

(3)Developing student's logical thinking and language expression ability, improving their subject consciousness, participation and sense of duty in learning. "I am asked to learn" becomes into "I want to learn".

However, its shortcomings have also been shown in the application process:

(1)There are difficulties in the implementation of experiential teaching in higher vocational English teaching. On the one hand the higher vocational students' interest in English study is low, on the other hand their English foundation is really weak. That requires teachers to carefully select the material in which students are interested in order to arouse students' interest in joining teaching activities.

(2)It takes a lot of time for students to experience the simulated language situation in class, which leads to the increase of the English class hours and slow teaching progress, and would take up the time of teaching other knowledge. And it does not conform to the trend of increasing the learning time of professional skills in higher vocational education reform.

(3)Experiential English teaching is of low universality, especially for the students with weak English level. A lot of experience and practice of the language cause much trouble to them.

(4)Experiential English teaching does not attache importance to student's reading ability, but values more about developing practical ability of the language by playing roles or finishing tasks in specific context, therefore the textbooks are easier to read.

\section{CONCLUSION}

As a kind of teaching model, experiential English teaching in higher vocational college not only requests higher quality students, but also higher-quality teachers. On the one hand teachers should have sharp observation and creativity to select proper materials for class discussion and motivating students' interest; on the other hand teachers should be good at organizing classroom teaching, being efficient, treating every student fairly and summing up the using and communicative roles of the language. Besides, the effective implementation of experiential English teaching relies on the support of school, 
such as the implementation of collectively preparing class in groups and providing supporting external environment.

\section{ACKNOWLEDGMENT}

Liu Hongwei, (1966.8-), Director of Teaching Affairs Office of Weifang Vocational College, Professor. Research orientation: teaching research and management.

\section{REFERENCES}

[1] Yang Min, Song Yunxia, Exploration and reflection of experiential English teaching [J]. Adult Education, 2010, 30(08):77-78.

[2] Ruan Wenqi, Dai Rui, Practice of experiential English teaching-teaching exploration of English majors in newly built undergraduate colleges and universities [J]. New West, 2011(09):216+238.

[3] Kong Qingyan, Hu Zhuanglin, GUI shichun, Jia Guodong, Focus on Experiencing English [J]. China University Teaching, 2003(08):39-41.

[4] Huang Yuhua, Liang Youzhen, Study on experiential English teaching [J]. Higher Education Forum, 2008(06):100-101+104.

[5] V. Kohonen, Experiential language learning: Second language learning as cooperative learner education. In D. Nunan (Ed.), Collaborative Language Learning and Teaching. Cambridge University Press. 1992.

[6] Nunan, D. Tradition and Change in the ELT Curriculum. ELT in China 2001- Papers presented at the 3rd International Symposium on ELT in China. [C] Foreign Language Teaching and Research Press, 2003. 